Article

\title{
"Deceived" Concentrated Immobilized Cells as Biocatalyst for Intensive Bacterial Cellulose Production from Various Sources
}

\author{
Nikolay Stepanov and Elena Efremenko * \\ Faculty of Chemistry, Lomonosov Moscow State University, Moscow 119991, Russia; na.stepanov@gmail.com \\ * Correspondence: elena_efremenko@list.ru; Tel.: +7-495-939-3170
}

Received: 21 December 2017; Accepted: 15 January 2018; Published: 18 January 2018

\begin{abstract}
A new biocatalyst in the form of Komagataeibacter xylinum B-12429 cells immobilized in poly(vinyl alcohol) cryogel for production of bacterial cellulose was demonstrated. Normally, the increased bacteria concentration causes an enlarged bacterial cellulose synthesis while cells push the polysaccharide out to pack themselves into this polymer and go into a stasis. Immobilization of cells into the poly(vinyl alcohol) cryogel allowed "deceiving" them: bacteria producing cellulose pushed it out, which further passed through the pores of cryogel matrix and was accumulated in the medium while not covering the cells; hence, the latter were deprived of a possible transition to inactivity and worked on the synthesis of bacterial cellulose even more actively. The repeated use of immobilized cells retaining $100 \%$ of their metabolic activity for at least 10 working cycles (60 days) was performed. The immobilized cells produce bacterial cellulose with crystallinity and porosity similar to polysaccharide of free cells, but having improved stiffness and tensile strength. Various media containing sugars and glycerol, based on hydrolysates of renewable biomass sources (aspen, Jerusalem artichoke, rice straw, microalgae) were successfully applied for bacterial cellulose production by immobilized cells, and the level of polysaccharide accumulation was 1.3-1.8-times greater than suspended cells could produce.
\end{abstract}

Keywords: bacterial cellulose; poly(vinyl alcohol); cell immobilization; hydrolysates of renewable biomass

\section{Introduction}

Currently, the interest in bacterial cellulose (BC) is increasing because of its possible use in such areas as medicine, food and textile industries, the production of new nanocomposite materials based on it and the solution of environmental problems [1-4]. First of all, this is due to the fact that BC is nontoxic and biocompatible material with an increased water-holding capacity, high tensile strength, as well as elasticity and porosity [5,6]. Unlike plant cellulose, BC does not require isolation and purification of lignin and hemicellulose, so the processes of producing $\mathrm{BC}$ are much less costly and energy-consuming [7].

Broadening of the scope and applications of BC is directly dependent on the availability of productive processes that provide high yields of this valuable biotechnological product [8]. Acetic acid bacteria in a static culture are mainly used to produce BC $[9,10]$. Analysis of known results enables determination of several main problems of BC production in general. It is a rather long process (up to $336 \mathrm{~h}$ ), and the final product yield is influenced by many factors (type and concentration of the carbon source in the medium, composition and $\mathrm{pH}$ of the nutrient medium) [11]. Various carbon sources were examined for the purpose of $\mathrm{BC}$ synthesis, while glucose appeared to be the high-usage carbon source for the synthesis of BC [12]. However, when bacterial cells are grown, gluconic acid accumulates in a glucose-containing medium, which lowers the $\mathrm{pH}$ of the medium and reduces the level of $\mathrm{BC}$ 
synthesis [10]. The adjustment of $\mathrm{pH}$ with $\mathrm{CaCO}_{3}$ results in inhibition of several main enzymes participating in the $\mathrm{BC}$ production since they contain bivalent metal ions in their active sites. In order to avoid this, researchers attempt to replace glucose as a major carbon source completely or partially with other substrates as the productivity of cells producing $B C$ is often higher when using these substrates than in a medium with glucose [13-15], The possible use of non-food substrates (renewable biomass sources, in particular) in the form of hydrolysates of various wastes is extremely attractive for scalable BC biosynthesis [16-19]. However, such raw materials and wastes often require preliminary physicochemical pretreatment for sugar releasing, and the obtained media may contain substances inhibiting the metabolic activity of cells [20]. Moreover, variations in chemical composition are inherent to natural biomass sources, requiring an increased cell capability to adapt to changing cultivation conditions and to keep the process productivity at a desired level. In this regard, the efficient approach to $\mathrm{BC}$ production enabling cells to improve their resistance to varying conditions of $\mathrm{BC}$ accumulation when the media discussed are employed should be offered.

Another problem associated with obtaining BC is the accumulation of polysaccharide in the process of cell growth and an increase in their concentration in the medium, that is cells partly spend the consumed substrate on the accumulation of their biomass, rather than on the synthesis of the target polymer [21]. The problem can be solved by the use of highly concentrated slowly-growing/non-growing cell populations, which are maintained in a membrane reactor to produce BC [22]. The problem is that cells synthesizing BC happen to be "included" in the polymer matrix that forms and accumulates around them. Since BC usually has a structure with nanoscale pores [12], the mass transfer of substances through them turns out to be rather hindered; the cells simply cease to function, and BC synthesis stops [23]. As a result, the obtained polymer has to be further processed and treated with alkaline agents in order to hydrolyze a significant biomass of cells that are "self-immured" in the BC so that a pure polymer could be obtained $[10,24]$. Thus, BC synthesis proves self-regulating.

Many researchers are trying to increase the level of BC synthesis by using traditional biotechnological approaches, namely by introducing into the nutrient medium some regulators of bacterial metabolism. For example, ethanol or organic acids (succinic, lactic, etc.) being cellular metabolites are applied to inhibit the basic metabolic processes in order to enhance the synthesis of by-products or substances necessary for the cell stabilization, in particular BC [25,26]. However, these measures appear not very successful, because the BC biosynthesis is "outside the main" metabolic processes in cells (Figure 1), with bacterial cellulose synthase (BC-synthase) (guanosine diphosphate-forming (GDP-glucose-beta-D-glucan glucosyltransferase, EC 2.4.1.29)), which is typically activated in the presence of cyclic diguanidine monophosphate (c-di-GMP) playing a major role in the $\mathrm{BC}$ biosynthesis [27]. The key idea of this activation is that the entry into the active center of BC-synthase is usually closed by an amino acid sequence loop held by the arginine R580 residue [28]. The c-di-GMP molecule appearing next to the active site of BC synthetase is coordinated with the R580 residue and enables it to weaken and lose its links to the functional residues of the loop, shielding the entrance to the active site. As a result, the entire loop that blocks the entrance to the catalytic center of the enzyme shifts to the side, making BC synthetase available for the substrate. Consequently, BC synthesis is predetermined by the molecule c-di-GMP appearing in the medium. As a rule, an artificial introduction of this substance into the medium leads to the activation of phosphodiesterases in the cells catalyzing decomposition of the substance. Therefore, the impact of the substance depends on whether it was synthesized by the cells themselves [28]. Therefore, in order to increase the synthesis of BC, it is necessary to foster the cell production of the substance. However, as is known, c-di-GMP is a "quorum factor," that is a substance that is synthesized by cells and is indispensable for their transition to a quorum state (when highly concentrated populations are formed, whose functioning is stabilized by the expression of "silent genes" and the synthesis of exopolysaccharides with a simultaneous decrease in the rate of active cell growth). Therefore, cells that produce BC should be stimulated to come into a quorum state, that is into a programmed genetic response of cells to their increased concentration per 
unit volume. The rectitude of these arguments is confirmed by recently published results, according to which BC synthesis is activated when cell concentration notably increases [29].

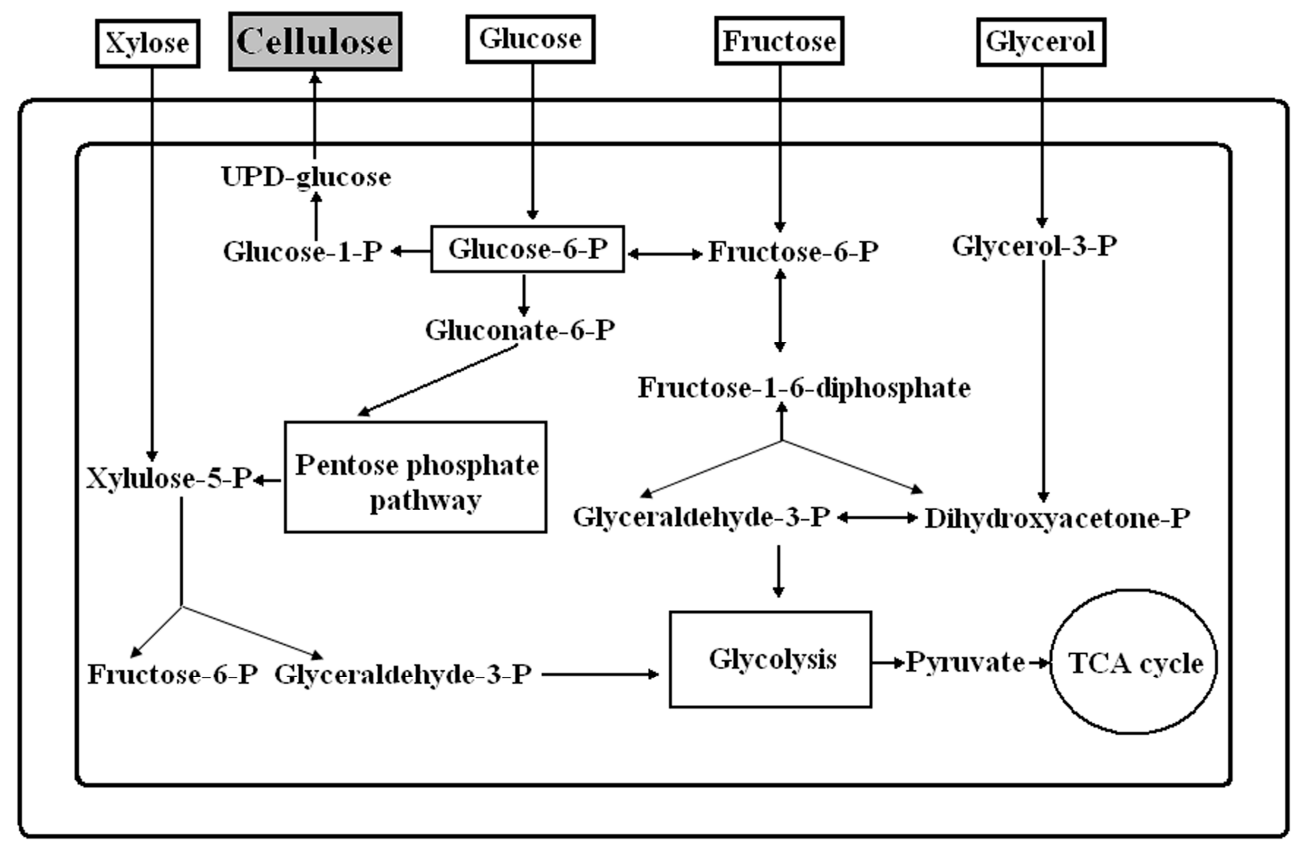

Figure 1. General scheme of sugars' conversion and bacterial cellulose synthesis by Komagataeibacter xylinum bacterial cells. TCA (tricarboxylic acid cycle).

Theoretically, in the case of BC producers, the immobilization of cells could allow one to obtain highly concentrated populations of cells where BC biosynthesis is regulated by such phenomena as quorum sensing [30]. Therefore, application of cell immobilization looks like a way to improve cell stabilization and increase process productivity. Despite the mentioned advantages of immobilization, currently examples of using immobilized producer cells of BC are rare. For example, to increase the synthesis of BC, a bioreactor was used with Acetobacter xylinum ATCC 700178 cells immobilized on a plastic composite support (PCS) produced on the basis of polypropylene. The synthesis of BC has been shown to increase 2.5-times as compared with free cells. The obtained BC samples had a higher degree of crystallinity (93\%) with a crystal size of $5.2 \mathrm{~nm}$. Such cellulose samples had improved tensile properties [22]. However, the researchers emphasized that the support used and the method of immobilization applied (cell adsorption on the surface of the carrier) did not enable long-term application of the immobilized cells in BC production.

The possibility and effectiveness of the application of immobilization methods differed from cell adsorption for $\mathrm{BC}$ producers, namely inclusion of bacterial cells into the gel matrices, under question, since according to the basic ideas with regard to the immobilization of microorganism cells, it is considered expedient to include cells in gel carriers only if the substrate and product for these cells are low molecular substances [31,32]. The highly molecular weight polysaccharide like BC is synthesized by cells being inside of the carrier, while BC should accumulate in the medium.

This situation seems nonsensical. However, having extensive and successful experience in applying poly(vinyl alcohol) (PVA) cryogels, which ensure favorable conditions for mass transfer processes for immobilized cells of various microorganisms [33,34], it was decided to try this medium to immobilize BC producers. The idea of such an investigation initially seemed ineffective, but the prospect of looking at the final result was encouraging (namely, at the $\mathrm{BC}$ cell synthesis and the polymer yield out of the carrier). Since PVA cryogel has a macroporous structure with a variable pore size, it is a stable in chemically different media and has high mechanical and thermal resistance while being inexpensive and generally recognized as safe [35], so its use seemed very attractive. 
Thus, the purpose of this study was to investigate the possibility and effectiveness of employing Komagataeibacter xylinum bacterial cells in an immobilized form with the use of a highly porous support (PVA cryogel) for cell inclusion in the process of $\mathrm{BC}$ biosynthesis while different culture media prepared using hydrolysates of various renewable sources of biomass (aspen, Jerusalem artichokes, wheat and rice straw) were applied. The comparison analysis of BC production by the same free and immobilized cells as biocatalysts was also very interesting.

\section{Results}

\subsection{Conditions Influencing BC Production by Immobilized Cells}

Initially, the samples of immobilized biocatalysts based on Komagataeibacter xylinum B-12429 cells were produced by using PVA cryogel in the form of granules and sheets (Figure 2).

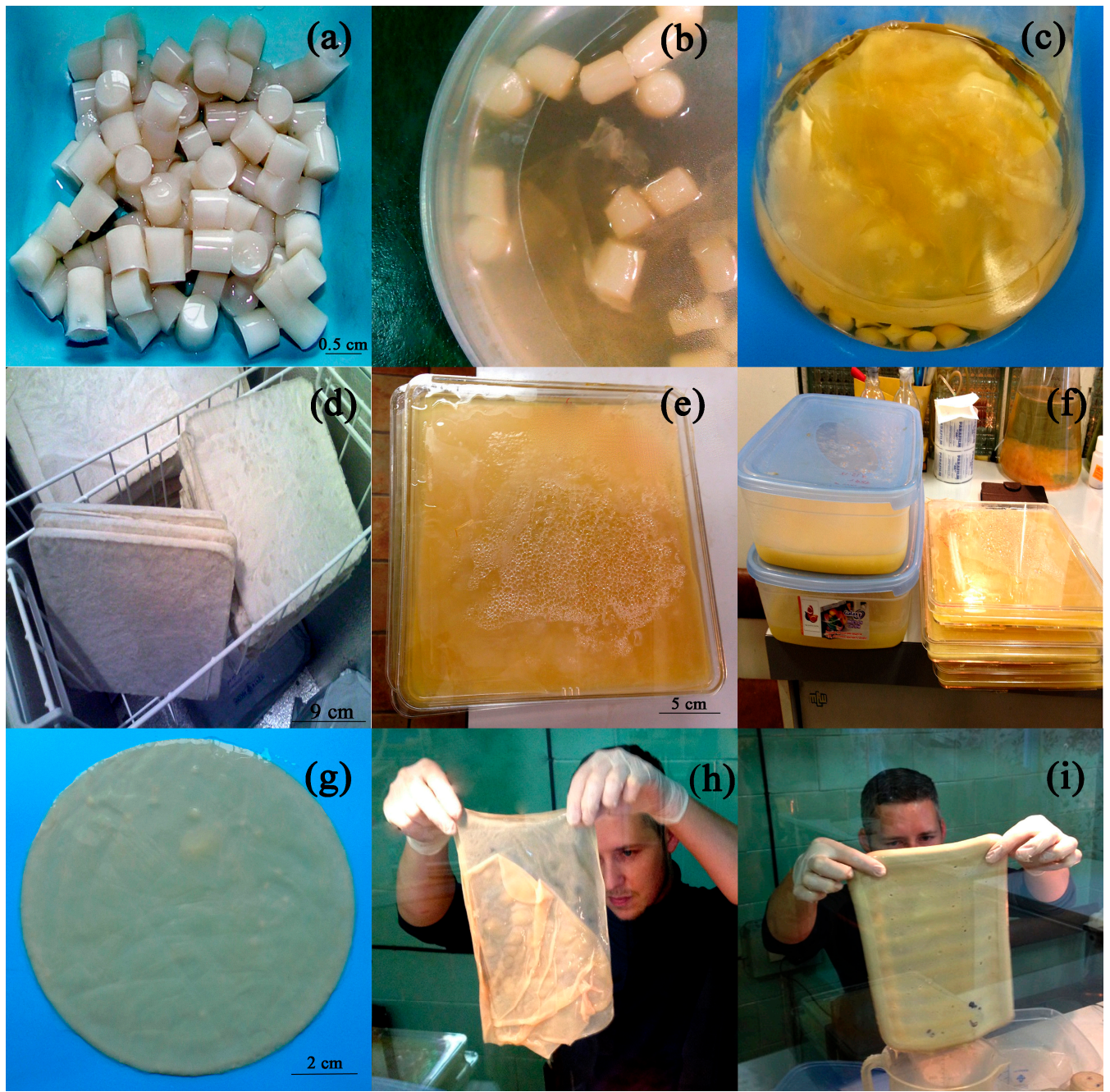

Figure 2. Bacterial cellulose (BC) production by immobilized Komagataeibacter xylinum cells. Images of immobilized biocatalysts based on poly(vinyl alcohol) (PVA) cryogel in the form of granules (a-c) or sheets (d-f); beginning of BC appearance from the granules with immobilized cells (b); PVA cryogel sheet with immobilized cells after biocatalyst obtaining and its placing into the nutritional medium $(\mathbf{e}, \mathbf{f})$; flask with granules containing immobilized cells and accumulated layer of BC (c); boxes with biocatalyst sheets for BC obtaining (f); BC formed in the flask (g) and box with cells immobilized in cryogel sheet (h); PVA cryogel sheet with immobilized cells after its use in the first cycle of BC production (i). 
Firstly, the immobilized biocatalyst shaped like granules was used for BC accumulation in the Hestrin-Schramm (HS) medium ( $\mathrm{pH} 5.6$ ) with $20 \mathrm{~g} / \mathrm{L}$ glucose. To better visualize the appearance of $\mathrm{BC}$ from granules with immobilized cells, the sample of the biocatalyst was placed into a Petri dish (Figure 2b). It became clear that immobilized cells weaved and push out the pieces of $B C$ from the volume of polymeric granules (Figure $2 b$ ) that further combine into the joint $B C$ slice. Further, a portion of granules was inoculated into HS-medium for accumulation of $B C$ in flask (Figure 2c) to evaluate the efficacy of producing BC by using immobilized cells (Figure 3). A process using immobilized and free cells concurrently conducted during $190 \mathrm{~h}$ at a temperature of $28^{\circ} \mathrm{C}$. The initial concentrations of cells in the medium were the same and equaled $0.03 \mathrm{~g}$ cell dry weight $(\mathrm{CDW}) / \mathrm{L}$.
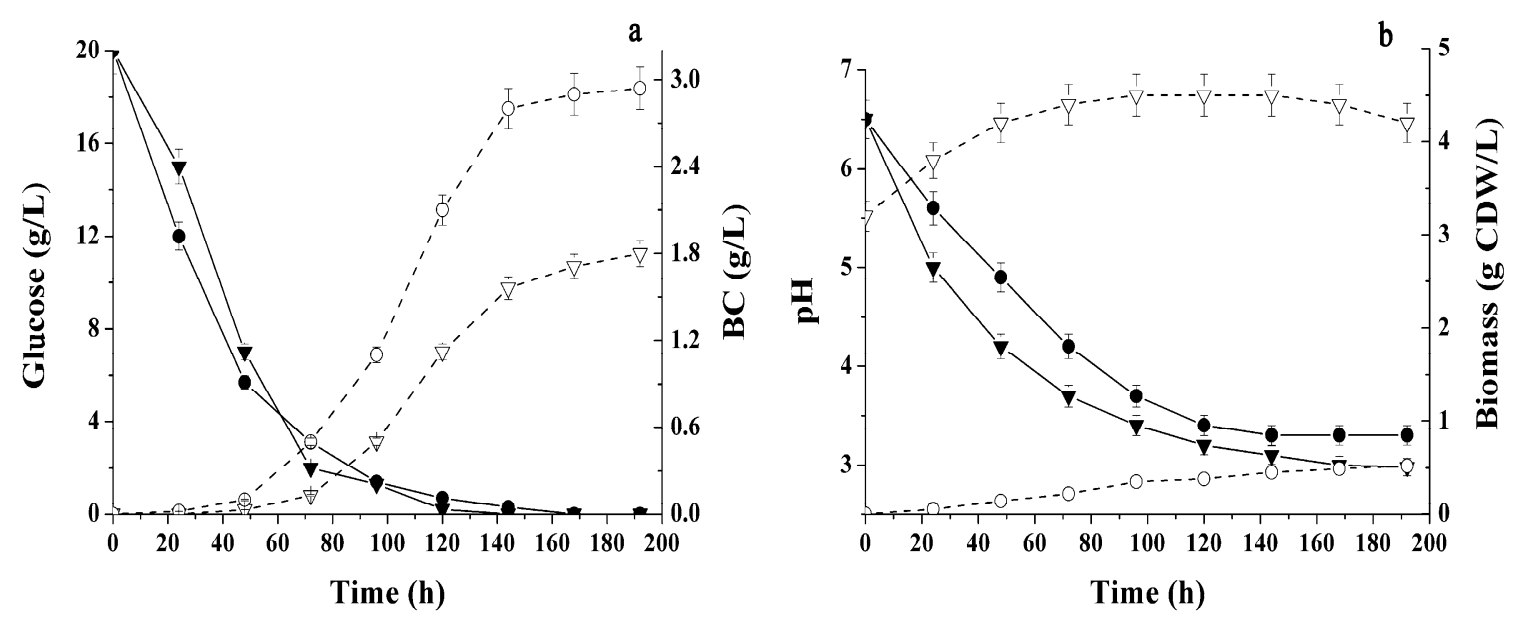

Figure 3. The kinetics of glucose consumption (black symbols) and BC production (white symbols) (a); $\mathrm{pH}$ changes (black symbols) and accumulation of free cell biomass (white symbols) (b) in the Hestrin-Schramm (HS)-medium with Komagataeibacter xylinum B-12429 cells taken in free (triangles) and immobilized (circles) forms. CDW (cell dry weight).

It was shown that almost all the glucose amount initially introduced into the medium was consumed by the cells by $120 \mathrm{~h}$ (Figure 3a). Accumulation of BC was 1.6-times higher with immobilized cells employed in comparison with free producers. The accumulation of free cells in the medium was negligible in the case of immobilized biocatalyst and maximally amounted to $0.05 \mathrm{~g} C D W / \mathrm{L}$, which was six-times less in comparison with suspended cells used as BC producers (Figure 3b). Obviously, this process was followed by the decrease in $\mathrm{pH}$ of culture medium owing to accumulation of acidic metabolites, and in the case of immobilized cells it was notably less intensive especially for the first $70 \mathrm{~h}$ of cultivation.

The effect of varying the shape of immobilized biocatalyst (granules or sheets), as well as the concentration of cells initially introduced into the PVA cryogel on the process of BC producing by immobilized biocatalyst was investigated (Table 1). It was demonstrated that the rate of $B C$ accumulation in the medium slightly increases as the concentration of immobilized cells rises from 20-60 g CDW / kg in granules, whereas the general amount of PVA cryogel with entrapped cells was the same in all samples. There was no difference between concentrations of BC accumulated by cells immobilized in polymer matrix shaped like granules or sheets.

The use of increased concentration of immobilized cells in the PVA cryogel allows one to enlarge the cell concentration in the medium without changing the total amounts of biocatalysts implemented in the process. The introduction of cell biomass in the range 3.2-9.5 g CDW/L into immobilized biocatalyst did not result in the significant improvement of the process productivity, which was probably due to the limitation of immobilized cells along the substrate in the polymer support. Nevertheless, the presence of macroporous matrix such as PVA cryogel spatially dividing the cells between each other and concurrently allowing retaining a high volumetric concentration of cells 
appeared to change by a little bit the mentioned conception related to cell inoculum concentrations useful for BC production.

Table 1. The result of the application of immobilized biocatalyst of different shapes containing different concentrations of bacterial cell biomass in the synthesis of BC in an Hestrin-Schramm -medium with $20 \mathrm{~g} / \mathrm{L}$ of glucose. CDW, cell dry weight. BC, bacterial cellulose.

\begin{tabular}{cccc}
\hline $\begin{array}{c}\text { Shape of } \\
\text { Immobilized } \\
\text { Biocatalyst }\end{array}$ & $\begin{array}{c}\text { Dry Cell Biomass Concentration } \\
\text { in Immobilized Biocatalyst } \mathbf{( g / k g})\end{array}$ & BC (g/L) & $\begin{array}{c}\text { Biomass of Free Cells Accumulated } \\
\text { in the Medium }(\mathbf{g} \text { CDW/L) }\end{array}$ \\
\hline \multirow{3}{*}{ Granules } & 20 & $2.9 \pm 0.1$ & $0.50 \pm 0.03$ \\
& 40 & $3.4 \pm 0.2$ & $0.53 \pm 0.04$ \\
Sheets & 60 & $3.6 \pm 0.2$ & $0.57 \pm 0.05$ \\
\hline & 20 & $2.8 \pm 0.1$ & $0.75 \pm 0.05$ \\
& 60 & $3.2 \pm 0.2$ & $0.88 \pm 0.04$ \\
\hline
\end{tabular}

\subsection{Different Sugars and Glycerol as Sources for BC Synthesis}

Then, it was further investigated what the impact of the glucose concentration introduced into the medium on the yield of BC produced by immobilized biocatalyst in the same concentration of $9.5 \mathrm{~g} C D W / \mathrm{L}$ was. For this purpose, the glucose concentration ranging from 30-100 g/L was further applied (Figure 4). It was demonstrated that when the original concentration of glucose in the medium was $30 \mathrm{~g} / \mathrm{L}$, there was an increase in $\mathrm{BC}$ accumulation, and the $\mathrm{BC}$ productivity of the process was 1.25-time higher.
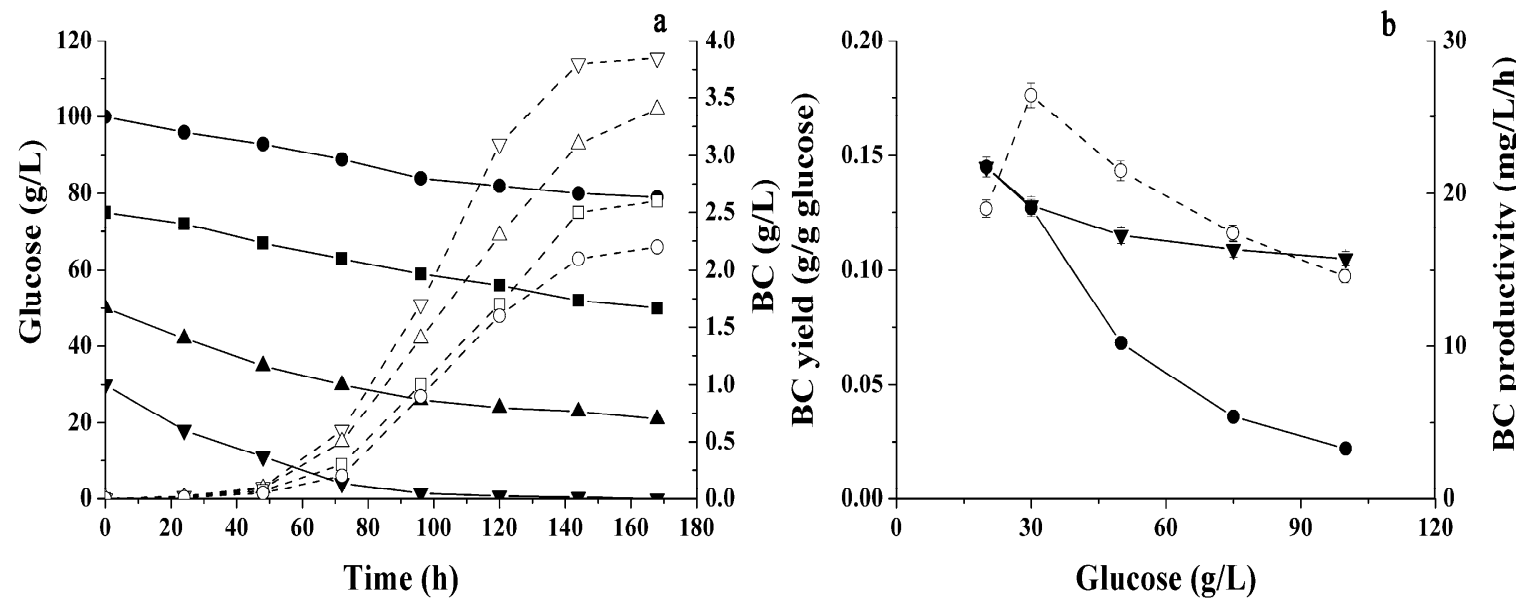

Figure 4. The kinetics of glucose consumption and BC production by immobilized Komagataeibacter xylinum B-12429 cells in the HS-medium with different glucose concentrations (g/L): $\boldsymbol{\nabla}-30, \mathbf{\Lambda}-50$, - 75, -100 (a). The BC output depending on the concentration of glucose consumed ( $\mathbf{\square})$, the BC output depending on the initial glucose concentration $(\bullet)$ and the rate of BC accumulation $(\bigcirc)$ by immobilized cells depending on the initial glucose concentration in the medium (b).

The optimal initial concentration of glucose in the medium appeared to be $30 \mathrm{~g} / \mathrm{L}$ (Figure 4), and when it was over this level, both parameters such as process productivity and the target product yield decreased with the consumed substrate taken into account. When the initial concentration of glucose in the medium was more than $50 \mathrm{~g} / \mathrm{L}$, immobilized cells produced BC 1.3-times less than during the same time period compared to the concentration of glucose at $30 \mathrm{~g} / \mathrm{L}$, while the glucose consumption rate decreased. Accumulation of free cells in the culture liquid was more pronounced at higher concentrations of glucose in the medium. Therefore, a part of the consumed substrate was 
obviously used by immobilized cells for free biomass accumulation instead of BC synthesis, since then, the use of glucose concentration over $30 \mathrm{~g} / \mathrm{L}$ appeared to be unreasonable.

The study was focused on the potential of using not only glucose, but other sugars as sources of carbon for BC obtaining (Table 2). To this end, various mono- and di-saccharides (as well as their mixtures at a concentration of $20 \mathrm{~g} / \mathrm{L}$ ) were introduced into the HS-medium instead of glucose; a parallel assessment of the level of BC was performed that was produced in these media by free and immobilized cells used in the same concentrations. The process was conducted over seven days at $28{ }^{\circ} \mathrm{C}$. Once again, immobilized cells provided the best indicators for the process, but both them and free cells showed a low BC yield in media with maltose and galactose taken as the main carbon source; xylose and arabinose happened to be almost non-convertible into BC by the bacterial strain used. In general, the experiment confirmed that the cells investigated can synthesize BC in media with mixtures of different sugars, and this created the grounds for further study of possibilities for producing $B C$ in media with hydrolysates of various renewable raw materials, in which such mixtures of sugars are present.

Table 2. Concentration of BC produced by free and immobilized cells of Komagataeibacter xylinum B-12429 in the media with different sugars.

\begin{tabular}{cccc}
\hline \multirow{2}{*}{ Sugar } & Concentration $(\mathrm{g} / \mathrm{L})$ & \multicolumn{2}{c}{ BC $(\mathrm{g} / \mathrm{L})$} \\
\cline { 3 - 4 } & & Free Cells & Immobilized Cells \\
\hline Arabinose & 20 & $0.03 \pm 0.01$ & $0.07 \pm 0.01$ \\
Galactose & 20 & $0.08 \pm 0.01$ & $0.12 \pm 0.02$ \\
Glucose & 20 & $1.8 \pm 0.10$ & $3.6 \pm 0.20$ \\
Xylose & 20 & $0.19 \pm 0.02$ & $0.24 \pm 0.03$ \\
Maltose & 20 & $1.9 \pm 0.20$ & $0.08 \pm 0.01$ \\
Sucrose & 20 & $2.1 \pm 0.20$ & $2.8 \pm 0.20$ \\
Fructose & 20 & $1.9 \pm 0.10$ & $3.1 \pm 0.20$ \\
Glucose/Fructose & $10 / 10$ & $1.8 \pm 0.20$ & $3.2 \pm 0.20$ \\
Glucose/Sucrose & $10 / 10$ & $0.8 \pm 0.10$ & $2.4 \pm 0.20$ \\
Glucose/Xylose & $10 / 10$ & $1.8 \pm 0.10$ & $1.3 \pm 0.10$ \\
Glucose/Fructose & $15 / 5$ & $2.1 \pm 0.10$ & $2.8 \pm 0.20$ \\
Glucose/Fructose & $5 / 15$ & & $3.5 \pm 0.20$ \\
\hline
\end{tabular}

According to the literature data [14], glycerol may be a promising substrate for BC synthesis, which is a large-tonnage waste product of biodiesel production. In this connection, there has been a study of BC synthesis by immobilized cells in a medium with glycerol in various concentrations (Figure 5). It was found that an increase in the initial concentration of glycerol in the medium to $20 \mathrm{~g} / \mathrm{L}$ triggered an increase in the concentration of the BC accumulating. However, a subsequent increase in the concentration of glycerol did not lead to increased levels in BC synthesis. Thus, it was first shown that glycerol can be successfully applied as the main source of carbon for the $\mathrm{BC}$ production with immobilized cells, with the level of BC synthesis using $20 \mathrm{~g} / \mathrm{L}$ of glycerol comparable to the level of $\mathrm{BC}$ synthesis in media with $20 \mathrm{~g} / \mathrm{L}$ of glucose (Table 2 ).

\subsection{Various Hydrolysates of Renewable Raw Materials as Media for BC Obtaining}

To assess the range of the substrates spectrum employed to obtain BC produced by immobilized cells, a process was conducted during six days under static conditions using enzymatic hydrolysates of plant materials (aspen, rice straw, wheat straw and Jerusalem artichoke) (Table 3). The concentration of immobilized and free cells was identical $(9.5 \mathrm{~g} \mathrm{CDW} / \mathrm{L})$. The initial concentration of reducing sugars (RS) in hydrolysates was analyzed (Table 3). It should be noted that the main sugar in the aspen, rice and wheat straw hydrolysates was glucose, and in the artichoke hydrolysate, there were two main sugars: fructose $(36 \mathrm{~g} / \mathrm{L})$ and glucose $(17 \mathrm{~g} / \mathrm{L})$. It was found that the concentration of BC produced by immobilized cells in the artichoke enzymatic hydrolysate was 1.25 -time higher than it was in the 
enzymatic hydrolysates of aspen, wheat and rice straw. The advantages of immobilized cells were also obvious in this process.
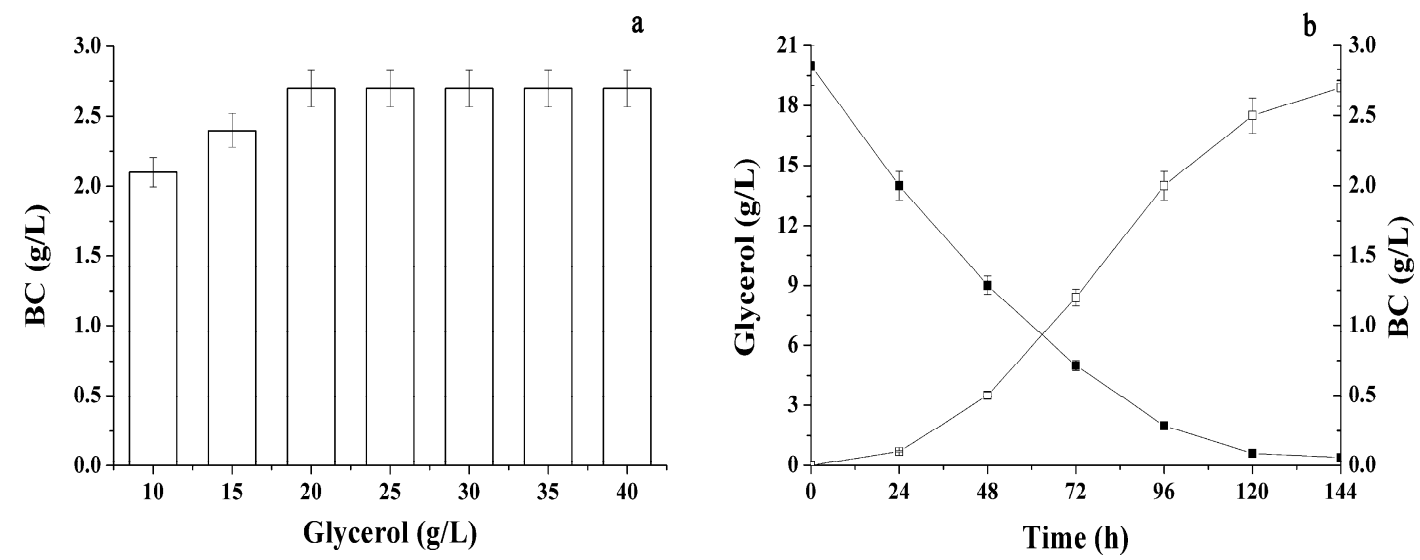

Figure 5. Influence of glycerol concentration in medium as a single carbon source on the synthesis of BC by immobilized Komagataeibacter xylinum cells (a) and the kinetics of glycerol consumption ( $\mathbf{\square})$ and BC production $(\square)$ in a medium with $20 \mathrm{~g} / \mathrm{L}$ glycerol (b).

Table 3. The production of BC by free and immobilized cells in media with hydrolysates of renewable raw materials. RS, reducing sugars.

\begin{tabular}{cccccc}
\hline \multirow{2}{*}{ Parameters } & \multirow{2}{*}{ Cells } & \multicolumn{4}{c}{ Hydrolysate } \\
\cline { 3 - 5 } & & Aspen & $\begin{array}{c}\text { Jerusalem } \\
\text { artichoke }\end{array}$ & Rice Straw & $\begin{array}{c}\text { Wheat } \\
\text { Straw }\end{array}$ \\
\cline { 3 - 6 } & & $11.0 \pm 0.5$ & $17.0 \pm 0.4$ & $7.8 \pm 0.2$ & $4.6 \pm 0.3$ \\
The residual & Free & $12.8 \pm 0.5$ & $22.7 \pm 0.4$ & $9.8 \pm 0.4$ & $7.8 \pm 0.3$ \\
\hline \multirow{2}{*}{ BC (g/L) } & Free & $2.2 \pm 0.2$ & $2.5 \pm 0.2$ & $2.4 \pm 0.2$ & $2.4 \pm 0.3$ \\
& Immobilized & $2.9 \pm 0.1$ & $4.5 \pm 0.2$ & $3.5 \pm 0.3$ & $3.6 \pm 0.2$ \\
\hline \multirow{2}{*}{ BC (g/g RS) } & Free & $0.07 \pm 0.01$ & $0.07 \pm 0.01$ & $0.08 \pm 0.01$ & $0.07 \pm 0.01$ \\
& Immobilized & $0.1 \pm 0.01$ & $0.15 \pm 0.02$ & $0.12 \pm 0.01$ & $0.12 \pm 0.01$ \\
\hline \multirow{2}{*}{ BC productivity (g/L/day) } & Free & $0.37 \pm 0.2$ & $0.42 \pm 0.3$ & $0.40 \pm 0.3$ & $0.40 \pm 0.3$ \\
& Immobilized & $0.48 \pm 0.2$ & $0.75 \pm 0.3$ & $0.60 \pm 0.3$ & $0.60 \pm 0.3$ \\
\hline
\end{tabular}

The process of the transformation of sugars present in biomass hydrolysates of micro- and macro-algae in BC was carried out (Table 4). The conditions of the process were identical to the previous experiment. The best indicators for BC synthesis were achieved in a medium with hydrolysates of Chlorella vulgaris biomass. However, for hydrolysates of macroalgae in general compared to hydrolysates of other renewable raw materials (Table 3), BC synthesis was lower, which may be explained by the high viscosity of the medium itself, which was caused by strongly swelling substrates, which prevented a highly effective mass transfer in the cells.

Table 4. Characteristics of the BC production by immobilized Komagataeibacter xylinum B-12429 cells in the media based on hydrolysates of biomass of micro- and macro-algae. RS, reducing sugars.

\begin{tabular}{ccccc}
\hline Hydrolysates & $\begin{array}{c}\text { Initial RS } \\
(\mathbf{g} / \mathbf{L})\end{array}$ & $\begin{array}{c}\text { Initial Glucose } \\
\mathbf{( g / L )}\end{array}$ & $\begin{array}{c}\text { Accumulated BC } \\
(\mathbf{g} / \mathbf{L})\end{array}$ & $\begin{array}{c}\text { BC Productivity } \\
\text { (g/L/day) }\end{array}$ \\
\hline Chlorella vulgaris C1 & $45.1 \pm 1.6$ & $29.0 \pm 0.8$ & $2.62 \pm 0.12$ & $0.440 \pm 0.020$ \\
Laminaria saccharina (brown) & $36.6 \pm 1.1$ & $5.1 \pm 0.1$ & $0.07 \pm 0.01$ & $0.012 \pm 0.001$ \\
Acanthophora muscoides (red) & $56.0 \pm 1.4$ & $13.2 \pm 0.3$ & $0.42 \pm 0.01$ & $0.070 \pm 0.010$ \\
Ulva lactuca (green) & $24.1 \pm 0.7$ & $7.3 \pm 0.2$ & $0.08 \pm 0.02$ & $0.013 \pm 0.002$ \\
\hline
\end{tabular}


In this regard, cells immobilized in PVA cryogel were reused multiple times under static conditions of BC production. For this purpose, the culture broth was replaced with a fresh medium (artichoke hydrolysate) after each working cycle in the reactor with immobilized cells (Figure 6). It was shown that immobilized cells maintain 100\% metabolic activity after 10 cycles under static conditions (60 days). The BC yield in this case amounted to $4.5 \pm 0.1 \mathrm{~g} / \mathrm{L}$, and the process productivity was $0.75 \pm 0.2 \mathrm{~g} / \mathrm{L} /$ day.
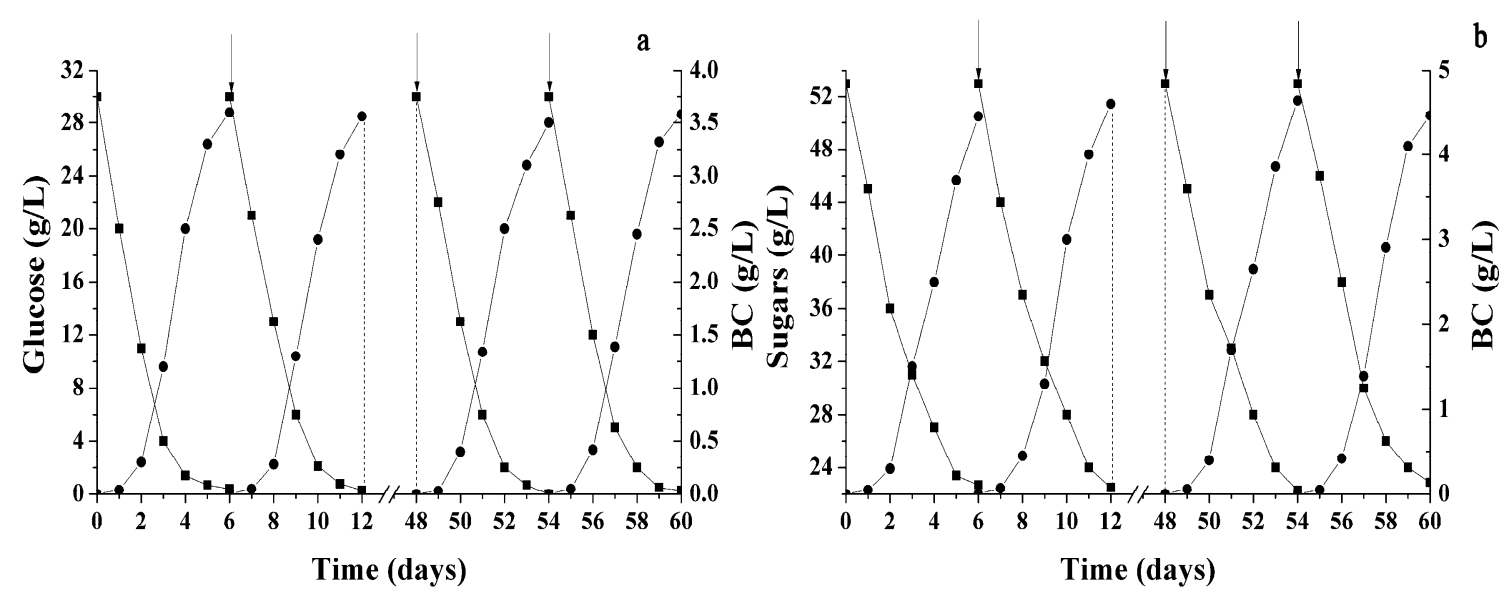

Figure 6. The sugars consumption $(\boldsymbol{\square})$ and BC accumulation $(\bullet)$ during the repeated use of Komagataeibacter xylinum B-12429 immobilized cells (9.5 CDW g/L) under static conditions. The broken lines and the arrows indicate the time when the culture broth was substituted with a fresh medium: containing glucose (a) or hydrolysate of Jerusalem artichoke (b).

One of the known advantages of immobilized cells is in the fact that they can be re-used many times in biotechnological procedures, and in this work, immobilized cells demonstrated a high metabolic activity after 10 working cycles under batch static conditions when the artichoke enzymatic hydrolysate was used as a carbon source (Figure 6).

At the next stage, the obtained BC samples' characteristics were investigated (Table 5). As it turned out, BC produced with immobilized cells under the same conditions with free cells had higher tear resistance, a 30\% greater thickness and a higher degree of polymerization. An even thicker and more durable BC film was formed by culturing immobilized cells on the hydrolysate of Jerusalem artichoke. As for the other properties, the resulting films were virtually identical.

Table 5. Properties of the BC produced by Komagataeibacter xylinum B-12429 cells in free and immobilized forms under identical conditions.

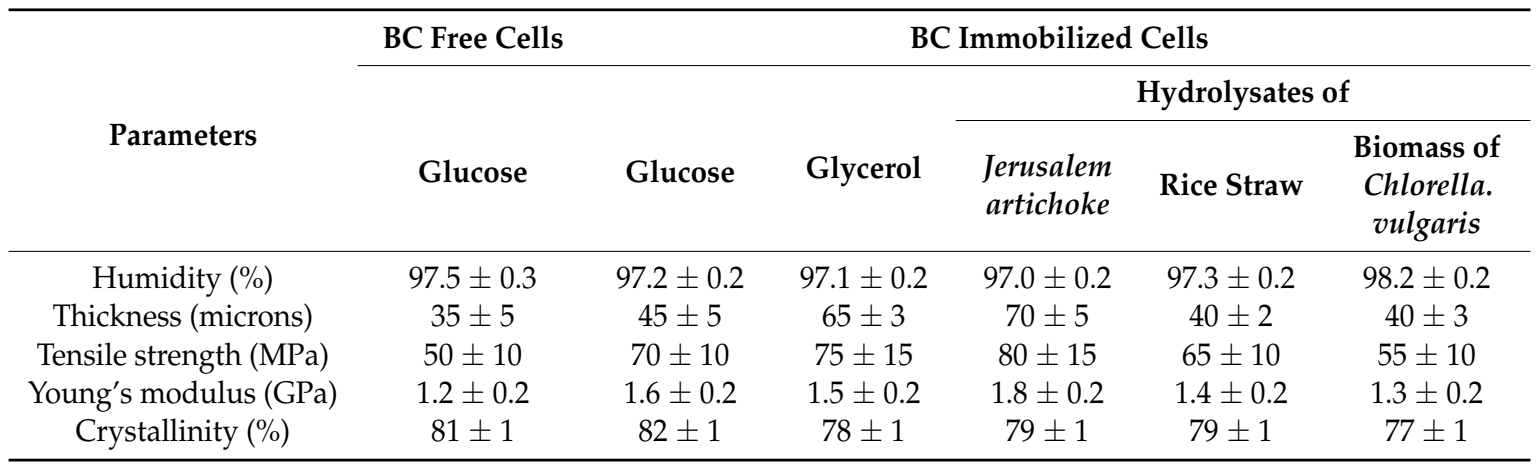




\section{Discussion}

The formation of BC three-dimensional interconnected reticular pellicle was previously reported for free cells cultivated under static conditions [10]. According to the results of Borzani and Desouza [36], the process of cellulose formation under static conditions is regulated by the concentration of free cells in the medium, and $\mathrm{BC}$ synthesis usually reaches its limit when the pellicle growth is downward, since BC entraps all bacteria, and bacterial cells become inactive due to insufficient oxygen supply through the $\mathrm{BC}$-cover with nanosized pores. The process of $\mathrm{BC}$ formation under static condition is regulated by air supply from the medium surface [37]. All these facts were generated in the following existing paradigm: when the bacterial cells are entrapped by adsorption into BC matrix, they are metabolically inactive, so the immobilization of $\mathrm{BC}$ producers is not a good means for successful production of the polysaccharide.

This work demonstrated the opposite results to this paradigm since the immobilization of BC-producing cells into PVA cryogel appeared to be efficient. Obviously, the effect was obtained owing to the difference between the porous characteristics of the specially-used PVA cryogel and naturally-forming $\mathrm{BC}$ that have micro- and nano-porous structures, correspondently.

An advantage of applying immobilized cells is the possibility of their repeated use, which can be quite beneficial in BC production, since it is known that during BC formation, free bacterial cells are adsorbed on its surface [10], making it necessary to constantly re-grow a fresh biomass of cells for BC producing, and the process of accumulation of BC producer biomass takes about $24 \mathrm{~h}[38,39]$. This means that with immobilized cells, it is possible to overcome this problem (loss of time for biomass accumulation de novo) in $\mathrm{BC}$ production.

The use of HS-medium for genus Komagataeibacter cells usually provides low enough levels of accumulated BC. For example, it was shown for K. hansenii cells that application of HS-medium results in production of $\mathrm{BC}$ in concentration of $0.422 \pm 0.007 \mathrm{~g}$ dry weight $(\mathrm{DW}) / \mathrm{L}$ for 14 days under static conditions [40]. In another publication, one can see that it possible to reach the BC accumulation by free cells in a concentration of $1.15 \pm 0.03 \mathrm{~g}$ DW/L by using HS-medium for seven days [41]. In this work, the BC was obtained under the same conditions (HS-medium, seven days and static cultivation) in concentrations of $1.74 \pm 0.03 \mathrm{~g} \mathrm{DW} / \mathrm{L}$ and $2.9 \pm 0.1 \mathrm{~g} \mathrm{DW} / \mathrm{L}$ when the free and immobilized Komagataeibacter xylinum cells were used, correspondently. Therefore, it appeared that production of BC depends not only on the medium used, but is influenced by both species of bacterial genus Komagataeibacter and the state of cells (suspended or immobilized) used in the process.

Medium $\mathrm{pH}$ was found to be critical for high BC productivity in many studies [10,11]. Obviously, gluconic acid reduces the $\mathrm{pH}$ of the medium down to 3.0, which can result in inhibition of $\mathrm{BC}$ accumulation. It is worth noting that in the medium with immobilized cells, there was also a notable decrease in $\mathrm{pH}$ of the medium (Figure 3) already after the first day of cultivation, but it was less than in samples with free cells, probably due to less formation of metabolites (of gluconic acid lowering the $\mathrm{pH}$, in particular) and more accumulation of BC.

The main purpose of this work was to develop and use a biocatalyst in the form of PVA cryogel-immobilized Komagataeibacter xylinum cells that can more efficiently produce BC in the batch static mode of cultivation as compared to free cells and to demonstrate that immobilization of bacteria is not a barrier for $\mathrm{BC}$ production.

The increased BC accumulation by immobilized Acetobacter xylinum ATCC 700178 cells as compared to their suspended form was previously published by Cheng et al. [22]. These experimental data were obtained with cells adsorbed on PCS, so the conditions of the immobilizing procedure were very friendly for cell survival. The results of the present investigation also demonstrated that the BC-producing cells were rather successful at surviving within the immobilization procedure consisting of freezing a cell suspension in a PVA solution with simultaneous formation of a cryogel matrix around the cells.

The concentration of BC-producing cells initially introduced into the process plays an important role in cellulose production. For instance, it was revealed that the increase in cell inoculum 
concentration over $5 \%(v / v)$ lowers the BC yield [42]. A similar conclusion done by other researches experimentally revealed how the amount of cell inoculum influences the BC production [43]. It appeared that when the inoculum concentration was decreased from $6-4 \%(v / v)$, the $B C$ accumulation was increased, and further increasing or decreasing the inoculum from $4 \%$, a decline in $\mathrm{BC}$ production was observed. Hornung et al. reported that for maximum BC production, the total cell count is not important, and the really significant quantity is the number of cells in the aerobic zone that are producing BC [23]. In this work, it was clearly shown that the initial concentration of cells in the medium can affect the BC production efficiency (Table 1), and an increase in cell concentration can be positive if the cells are in immobilized form, allowing one to separate them from each other in the frame of the porous matrix.

It is known then that a higher concentration of glucose is initially used for BC production, then lower $\mathrm{BC}$ yield can be observed, since the accumulation of cell-inhibiting concentrations of gluconic acid is occurring [10,44]. However, it was shown that BC production can be enhanced with increased glucose concentration up to $4 \%(w / v)$, but decreased above $4 \%$ along with the decline of pH-medium to below 2.58 [25].

In is known from previous publications that replacement of glucose-containing HS-medium for suspended cells by glucose-containing hydrolysates obtained on the basis of different wastes usually resulted in increased BC yield. For instance, the use of wheat straw hydrolysates provided $15.4 \mathrm{~g} / \mathrm{L} \mathrm{BC}$, and the level of $\mathrm{BC}$ accumulation was $50 \%$ higher as compared to the same parameter obtained using routine carbon sources [45]. BC from cotton cloth hydrolysate was obtained at a yield of $10.8 \mathrm{~g} / \mathrm{L}$, which was $83 \%$ higher than that from the culture grown on glucose-based medium [16]. A low-cost medium based on soya bean whey (SBW) was used for the production by Komagataeibacter sp. PAP1 [41]. The use of SBW medium increased BC production 3.6-fold compared to standard HS-medium. The use of corncob acid hydrolysate as a substrate for BC production by Gluconacetobacter xylinus cells provided a BC yield of $4 \mathrm{~g} / \mathrm{L}$ after 14 days of static cultivation. [44]. This investigation of the possible use of agricultural waste hydrolysates for BC production by immobilized cells demonstrated both productivity and $\mathrm{BC}$ yield at a high level in the medium containing artichoke enzymatic hydrolysate (Table 3). Most likely, this was due to the fact that the artichoke hydrolysate included a mixture of sugars (glucose and fructose). Zeng et al. noted that BC production with maple syrup was almost as high as when using pure fructose and much higher than when using glucose [46], and this fact is consistent with the viewpoint that the composition of sugars does not affect BC production if fructose exists in the medium, possibly because fructose activates a phosphoenolpyruvate-dependent phosphotransferase system in A. xylinum [47]. In addition, it is worth noting that all the glucose was fully utilized by cells, and the residual concentration of fructose was $22.7 \mathrm{~g} / \mathrm{L}$. In other hydrolysates, there was only glucose present.

The results obtained during multiple use of immobilized cells for BC production were very good and show promise to be used in practice, since Cheng et al. previously used PCS as a support for cell immobilization by adsorption of bacteria on the surface of the carrier and reported that this matrix and method did not contribute to a long period of employing the immobilized cells to produce BC [22].

The characteristics of BC samples produced by Komagataeibacter xylinum in both free and immobilized form under identical conditions demonstrated higher tear resistance and greater thickness, as well as a higher degree of polymerization of BC produced by immobilized cells. These results correlate with the data of other researches. For example, Suwanposri et al. noted that mechanical properties of BC accumulated in the medium based on the use of SBW had a 108\% increase in tensile strength and an $841 \%$ rise in Young's modulus over those of the HS medium [41]. However, the elongation at break of SBW film (3.28\%) was 3.4-time less than that of HS film (11.17\%). Huang et al. showed that BC produced from corncob acid hydrolysate had relatively high crystallinity and a high crystallinity index value (95.2\% and $93.8 \%$, respectively) [44]. The mechanical strength analysis done by Cheng et al. demonstrated that BC produced by being immobilized on PCS cells, similar to the pellicle form, improved its tensile strength to a point comparable to that observed in pellicle form [22]. 


\section{Materials and Methods}

\subsection{Microbial Strains and Culture Media}

A strain of Komagataeibacter xylinum B-12429 bacteria that derived from the Russian National Collection of Industrial Microorganisms (Moscow, Russia) was used in the study. The cell culture was carried out under aerobic conditions using the thermostatically-controlled shaker Adolf Kuhner AG (Basel, Switzerland) and BioSan ES-20 (Riga, Lithuania), which enabled continuous agitation of the culture liquid (150 rpm). To accumulate bacterial biomass at a temperature of $29 \pm 1{ }^{\circ} \mathrm{C}$, a culture medium, Hestrin-Schramm (HS), was used that had the following composition (g/L): glucose: 20; yeast extract: 5; peptone: $5 ; \mathrm{K}_{2} \mathrm{HPO}_{4} \cdot 3 \mathrm{H}_{2} \mathrm{O}: 2.7 ; \mathrm{MgSO}_{4} \cdot 7 \mathrm{H}_{2} \mathrm{O}: 0.5$; citric acid: $1.15, \mathrm{pH}: 5.6 \pm 0.2$.

\subsection{Cells' Immobilization}

Immobilized cells were produced using a patented procedure [48] by adding to a poly(vinyl alcohol) (PVA) aqueous solution (12\%) the biomass of bacteria cells previously separated from the culture medium by centrifugation with a Avanti J 25 (Beckman Coulter, Brea, CA, USA) at 8000 rpm during $15 \mathrm{~min}$. The final concentration of cell biomass in the obtained suspension was 20-60 $\mathrm{g}$ cell dry weight $(\mathrm{CDW}) / \mathrm{kg}$ (Table 1). The mixture of polymer solution and cells was stirred to obtain a homogeneous mass, which was afterwards used to form granules by dispensing the cell suspension into the PVA aqueous solution per $0.5 \mathrm{~mL}$ into each well of 96-well plates or the suspension was poured in an even layer $(0.5 \mathrm{~cm})$ into a flat bottom tank $(30 \times 30 \mathrm{~cm})$ to form a single layer of PVA cryogel with cells included in it. All plates were further frozen at $-20^{\circ} \mathrm{C}$, then kept in the frozen state for $24 \mathrm{~h}$ and later thawed at $8{ }^{\circ} \mathrm{C}$ during $8-12 \mathrm{~h}$ to obtain immobilized biocatalysts in the form of granules or sheets (Figure 2a-f).

\subsection{Analytical Methods}

The growth of the biomass of free cells was monitored by spectrophotometry. The degree of optical absorption of samples of the culture liquid at $540 \mathrm{~nm}$ was monitored using the spectrophotometer Agilent UV-853 (Agilent Technologies, Waldbronn, Germany), and the exact concentration of the cells was determined by calibration curves that establish the dependence of the optical absorption on the precisely known concentration of cells in a sample to be analyzed. Glucose concentration was determined by the enzymatic technique using a standard Impact reagent kit ("OOO Impact", Moscow, Russia). The Shomody-Nelson method was applied to determine the concentration of reducing sugars (RS) [49]. The concentration of fructose was determined by liquid chromatography under high pressure using a 1100 Agilent chromatograph with an amperometric detector (Agilent Technologies, Waldbronn, Germany) and a Dionex Carbopak PA-20 anion exchange column (Thermo Fisher Scientific, Waltham, MA, USA). A solution of $7.5 \mathrm{mM} \mathrm{NaOH}$ was used as the eluent.

Potentiometric measurements were conducted to control $\mathrm{pH}$ values of the media prepared and of samples selected in the experiments (a Corning Pinnacle $530 \mathrm{pH}-$ meter (Corning Incorporated, New York, NY, USA) was used).

To determine cell dry weight (CDW), we used a sample of the biomass separated from the culture liquid by centrifugation ( $8000 \mathrm{rpm}, 10 \mathrm{~min}$, Avanti J 25 centrifuge (Beckman Coulter, Brea, CA, USA)) that was brought to constant weight by drying at $+80^{\circ} \mathrm{C}$. A granule of the immobilized biocatalyst was also dried to constant weight. Knowing the initial concentrations of cells and the weight of the polymer when forming the granules, we calculated the concentrations of cells in the immobilized biocatalyst using the dry weight parameters.

\subsection{BC Production}

The following variant of HS-medium $(\mathrm{g} / \mathrm{L})$ was used to produce BC (Figure $2 \mathrm{~g}, \mathrm{~h}$ ): peptone: 5 ; yeast extract, $5 ; \mathrm{K}_{2} \mathrm{HPO}_{4}, 2.7 ; \mathrm{MgSO}_{4}, 0.5$; citric acid, 1.15 ; but its $\mathrm{pH}$ value was adjusted to $7.0 \pm 0.1$ with $2 \mathrm{M} \mathrm{KOH}$. The concentration of glucose was varied (20-100 g/L) in the medium. The process 
was conducted at $28^{\circ} \mathrm{C}$ during 6-7 days under static conditions in a 500-mL Erlenmeyer flask (Purex, Corning Incorporated, New York, NY, USA) with $100 \mathrm{~mL}$ of medium.

Free cells and biocatalysts shaped like granules or sheets (Figure 2c,i) with immobilized cells were used multiple times under the same conditions to produce BC. In some experiments, the glucose was replaced in HS-medium by glycerol. In experiments with hydrolysates of renewable sources, the HS-medium was completely replaced by them.

We purified the $\mathrm{BC}$ film by placing it into a $0.5 \% \mathrm{NaOH}$ solution for $24 \mathrm{~h}$ at a temperature of $25-27^{\circ} \mathrm{C}$ and stirring it periodically. After the BC-film was washed in distilled water, its properties were investigated.

\subsection{Pretreatment and Fermentative Hydrolysis of Biomass}

Samples of aspen, rice and wheat straw were pre-dried to a residual humidity of 7-10\% and milled to a particle size of 100-300 microns using an impeller mill Mikrosilema IM-450 (Techpribor, Schekino, Russia). Physicochemical pretreatment of the renewable biomass was carried out in the presence of $1.5 \% \mathrm{H}_{2} \mathrm{SO}_{4}$ at $150{ }^{\circ} \mathrm{C}$ during $1 \mathrm{~h}$. A mixture of commercial preparations of cellulases such as Spezyme CP (Dupont, Ney York, NY, USA) and Novozyme-188 (Novozymes Corp., Copenhagen, Denmark) was used for the enzymatic hydrolysis of renewable raw materials (the ratio between preparations in the mixture was 3:1). Enzyme preparations were introduced into the reaction medium (10 $\mathrm{mg}$ of protein per $1 \mathrm{~g}$ of the substrate dry matter). Hydrolysis was carried out in the medium based on $0.05 \mathrm{M}$ citrate buffer ( $\mathrm{pH} 5.0$ ) at $50{ }^{\circ} \mathrm{C}$ and with constant stirring at $250 \mathrm{rpm}$ during $24 \mathrm{~h}$.

Jerusalem artichoke tubers (humidity: $0 \%$ ) were hydrolyzed by introducing into the crushed mass of enzyme preparations of inulinases from Aspergillus niger (Novozymes Corp., Copenhagen, Denmark), cellulases ( $2 \mathrm{mg}$ of total protein/g of the dry substrate) and $\beta$-glucosidase (40 units of cellobiase activity/g of the dry substrate). The hydrolysis was carried out without addition of water at $50{ }^{\circ} \mathrm{C}, \mathrm{pH} 6.5$ and constant stirring at $250 \mathrm{rpm}$ for $6 \mathrm{~h}$. At the end of the process, the hydrolysate was separated from the non-hydrolyzed biomass by centrifuge (Beckman Coulter, Brea, CA, USA) at $6000 \mathrm{rpm}$ during $10 \mathrm{~min}$.

In all samples of obtained hydrolysates, the $\mathrm{pH}$ value was adjusted with $2 \mathrm{M} \mathrm{KOH}$ up to $7.0 \pm 0.1$ before their application in BC production.

\subsection{Characterization of BC Samples}

The tensile strength and Young's modulus of the BC pellicles were analyzed through tensile tests, using a testing machine BP DLC 1 (Tochpribor, Moscow, Russia). The specimens were cut in a rectangular shape using a paper cutting machine, producing samples with dimensions of $1 \mathrm{~cm} \times 7 \mathrm{~cm}$ individual sample thickness. Three samples were cut per pellicle and used in each experimental session. The BC samples were stretched at a constant speed of $5 \mathrm{~mm} / \mathrm{min}$ until the failure of the sample occurred. A Mitutoyo digital thickness indicator was used to measure the thickness of each specimen (Mitutoyo Corp., Kanagawa, Japan).

The crystallinity index of BC was measured using X-ray diffractometric analysis as described by Mohammadkazemi et al. [50]. A multi-purpose diffractometer Philips PW3040/60 (Philips, Amsterdam, The Netherlands) was used in this work. Analysis of polymerization degree and purity of BC was done as described by Lu et al. [5]. Dried BC samples were soaked in deionized water during $12 \mathrm{~h}$ at room temperature, and the weight in water was measured by harnessing the sample in a device, which suspended the sample in water. The porosity was calculated using the following formula: porosity $(\%)=($ wet weight - dry weight $) /$ (wet weight - weight in water $) \times 100$.

All experiments were carried out in triplicate. The microbiological purity of cultures used in this work was monitored by microscopy using an Axio Imager Z2m microscope (Carl Zeiss MicroImaging GmbH, Jena, Germany). 


\section{Conclusions}

In summary, these studies revealed the high efficacy of a new biocatalytic system in the form of bacterial cells immobilized in PVA cryogel for BC production. By using the porous support as the matrix for the cell immobilization, it becomes possible to deceive cells, and we did not allow them to cover themselves with the BC layer, which normally stops the cell functioning. Immobilized cells in a state of highly concentrated populations have substantially higher rates of metabolic processes and a higher yield of the target product when compared with free cells, resulting in increased efficiency of the overall process of BC production. Furthermore, these studies demonstrated the possibility of repeated use of immobilized cells retaining $100 \%$ of their metabolic activity for at least 10 working cycles ( 60 days). The approach based on the application of immobilized cells enables obtaining BC possessing the same crystallinity and porosity as in the process with free cells, but having improved stiffness and tensile strength. Various media containing sugars and glycerol, based on hydrolysates of agricultural materials and biomass of microalgae, were successfully applied as effective sources for BC production by immobilized cells.

Acknowledgments: This work was financially supported by the Russian Foundation for Basic Research (Grant No. 16-08-00457).

Author Contributions: E.E. conceived of and designed the experiments. N.S. performed the experiments. N.S. and E.E. analyzed the data and wrote the paper.

Conflicts of Interest: The authors declare no conflict of interest.

\section{References}

1. Ullah, H.; Santos, H.A.; Khan, T. Applications of bacterial cellulose in food, cosmetics and drug delivery. Cellulose 2016, 23, 2291-2314. [CrossRef]

2. Sulaeva, I.; Henniges, U.; Rosenau, T.; Potthast, A. Bacterial cellulose as a material for wound treatment: Properties and modifications. A review. Biotechnol. Adv. 2015, 33, 1547-1571. [CrossRef] [PubMed]

3. Rajwade, J.M.; Paknikar, K.M.; Kumbhar, J.V. Applications of bacterial cellulose and its composites in biomedicine. Appl. Microbiol. Biotechnol. 2015, 99, 2491-2511. [CrossRef] [PubMed]

4. Mohite, B.V.; Patil, S.V. A novel biomaterial: Bacterial cellulose and its new era applications. Biotechnol. Appl. Biochem. 2014, 61, 101-110. [CrossRef] [PubMed]

5. Lu, H.; Jiang, X. Structure and properties of bacterial cellulose produced using a trickling bed reactor. Appl. Biochem. Biotechnol. 2014, 172, 3844-3861. [CrossRef] [PubMed]

6. Gayathry, G.; Gopalaswamy, G. Production and characterization of bacterial cellulose fibre from Acetobacter xylinum. Indian J. Fibre Text. Res. 2014, 39, 93-96.

7. Keshk, S.M.A.S. Bacterial cellulose production and its industrial applications. J. Bioprocess Biotech. 2014, 4, 150. [CrossRef]

8. Huang, Y.; Chen, Y. An overview of fermentation production and application of bacterial cellulose. Adv. Mater. Res. 2013, 627, 878-884. [CrossRef]

9. Kongruang, S. Bacterial cellulose production by Acetobacter xylinum strains from agricultural waste products. Appl. Biochem. Biotechnol. 2008, 148, 245-256. [CrossRef] [PubMed]

10. Chawla, P.R.; Ishwar, B.B.; Shrikant, A.S.; Rekha, S.S. Microbial cellulose: Fermentative production and applications. Food Technol. Biotechnol. 2009, 47, 107-124.

11. Lin, S.P.; Calvar, I.L.; Catchmark, J.M.; Liu, J.-R.; Demirci, A.; Cheng, K.-C. Biosynthesis, production and applications of bacterial cellulose. Cellulose 2013, 20, 2191-2219. [CrossRef]

12. Huang, Y.; Zhu, C.; Yang, J.; Nie, Y.; Chen, C.; Sun, D. Recent advances in bacterial cellulose. Cellulose 2014, 21, 1-30. [CrossRef]

13. Pourramezan, G.Z.; Roayaei, A.M.; Qezelbash, Q.R. Optimization of culture conditions for bacterial cellulose production by Acetobacter sp. 4B-2. Biotechnology 2009, 8, 150-154. [CrossRef]

14. Tsouko, E.; Kourmentza, C.; Ladakis, D.; Kopsahelis, N.; Mandala, I.; Papanikolaou, S.; Paloukis, F.; Alves, V.; Koutinas, A. Bacterial cellulose production from industrial waste and by-product streams. Int. J. Mol. Sci. 2015, 16, 14832-14849. [CrossRef] [PubMed] 
15. Jalili Tabaii, M.; Emtiazi, G. Comparison of bacterial cellulose production among different strains and fermented media. Appl. Food Biotechnol. 2016, 3, 35-41.

16. Hong, F.; Guo, X.; Zhang, S.; Han, S.F.; Yang, G.; Jönsson, L.J. Bacterial cellulose production from cotton-based waste textiles: Enzymatic saccharification enhanced by ionic liquid pretreatment. Bioresour. Technol. 2012, 104, 503-508. [CrossRef] [PubMed]

17. Chen, L.; Hong, F.; Yang, X.-X.; Han, S.-F. Biotransformation of wheat straw to bacterial cellulose and its mechanism. Bioresour. Technol. 2013, 135, 464-468. [CrossRef] [PubMed]

18. Cheng, Z.; Yang, R.; Liu, X. Production of bacterial cellulose by Acetobacter xylinum through utilizing acetic acid hydrolysate of bagasse as low-cost carbon source. BioResources 2017, 12, 1190-1200. [CrossRef]

19. Cheng, Z.; Yang, R.; Liu, X.; Liu, X.; Chen, H. Green synthesis of bacterial cellulose via acetic acid pre-hydrolysis liquor of agricultural corn stalk used as carbon source. Bioresour. Technol. 2017, 234, 8-14. [CrossRef] [PubMed]

20. Jönsson, L.J.; Martín, C. Pretreatment of lignocellulose: Formation of inhibitory by-products and strategies for minimizing their effects. Bioresour. Technol. 2016, 199, 103-112. [CrossRef] [PubMed]

21. Campano, C.; Balea, A.; Blanco, A.; Negro, C. Enhancement of the fermentation process and properties of bacterial cellulose: A review. Cellulose 2016, 23, 57-91. [CrossRef]

22. Cheng, K.C.; Catchmark, J.M.; Demirci, A. Enhanced production of bacterial cellulose by using a biofilm reactor and its material property analysis. J. Biol. Eng. 2009, 3, 12. [CrossRef] [PubMed]

23. Hornung, M.; Ludwig, M.; Gerrard, A.M.; Schmauder, H.-P. Optimizing the production of bacterial cellulose in surface culture: Evaluation of substrate mass transfer influences on the bioreaction (Part 1). Eng. Life Sci. 2006, 6, 537-545. [CrossRef]

24. Meftahi, A.; Khajavi, R.; Rashidi, A.; Rahimi, M.K.; Bahador, A. Effect of purification on nano microbial cellulose pellicle properties. Proced. Mater. Sci. 2015, 11, 206-211. [CrossRef]

25. Usha Rani, M.; Anu Appaiah, K.A. Production of bacterial cellulose by Gluconacetobacter hansenii UAC09 using coffee cherry husk. J. Food Sci. Technol. 2013, 50, 755-762. [CrossRef] [PubMed]

26. Lu, H.; Jia, Q.; Chen, L.; Zhang, L. Effect of organic acids on bacterial cellulose produced by Acetobacter xylinum. RRJMB 2016, 5, 1-6.

27. Römling, U.; Galperin, M.Y.; Gomelsky, M. Cyclic di-GMP: The first 25 years of a universal bacterial second messenger. Microbiol. Mol. Biol. Rev. 2013, 77, 1-52. [CrossRef] [PubMed]

28. Morgan, J.L.W.; McNamara, J.T.; Zimmer, J. Mechanism of activation of bacterial cellulose synthase by cyclic-di-GMP. Nat. Struct. Mol. Biol. 2014, 21, 489-496. [CrossRef] [PubMed]

29. Römling, U.; Galperin, M.Y. Bacterial cellulose biosynthesis: Diversity of operons, subunits, products, and functions. Trends Microbiol. 2015, 23, 545-557. [CrossRef] [PubMed]

30. Srivastava, D.; Waters, C.M. A tangled web: Regulatory connections between quorum sensing and cyclic di-GMP. J. Bacteriol. 2012, 194, 4485-4493. [CrossRef] [PubMed]

31. Lebrun, L.; Junter, G.-A.; Jouenne, T.; Mignot, L. Exopolysaccharide production by free and immobilized microbial cultures. Enzyme Microb. Technol. 1994, 16, 1048-1054. [CrossRef]

32. Santos, E.L.I.; Rostro-Alanís, M.; Parra-Saldívar, R.; Alvarez, A.J. A novel method for bioethanol production using immobilized yeast cells in calcium-alginate films and hybrid composite pervaporation membrane. Bioresour. Technol. 2018, 247, 165-173. [CrossRef] [PubMed]

33. Efremenko, E.N.; Nikolskaya, A.B.; Lyagin, I.V.; Senko, O.V.; Stepanov, N.A.; Maslova, O.V.; Mamedova, F.; Varfolomeyev, S.D. Production of biofuels from pretreated microalgae biomass by anaerobic fermentation with immobilized Clostridium acetobutylicum cells. Bioresour. Technol. 2012, 114, 342-348. [CrossRef] [PubMed]

34. Efremenko, E.N.; Senko, O.V.; Aleskerova, L.E.; Alenina, K.A.; Mazhul, M.M.; Ismailov, A.D. Biosensors based on the luminous bacteria photobaterium phosphoreum immobilized in polyvinyl alcohol cryogel for the monitoring of ecotoxicants. Appl. Biochem. Microbiol. 2014, 50, 477-482. [CrossRef]

35. Kumar, A. Supermacroporous Cryogels: Biomedical and Biotechnological Applications, 1st ed.; CRC Press: Boca Raton, FL, USA, 2016; p. 496; ISBN 978-1482228816.

36. Borzani, W.; Souza, S.J. Mechanism of the film thickness increasing during the bacterial production of cellulose on non-agitated liquid media. Biotechnol. Lett. 1995, 17, 1271-1272. [CrossRef]

37. Budhiono, A.; Rosidi, B.; Taher, H.; Iguchi, M. Kinetic aspects of bacterial BC formation in nata-de-coco culture system. Carbohydr. Polym. 1999, 40, 137-143. [CrossRef] 
38. Ha, J.H.; Shehzad, O.; Khan, S.; Lee, S.Y.; Park, J.W.; Khan, T.; Park, J.K. Production of bacterial cellulose by a static cultivation using the waste from beer culture broth. Korean J. Chem. Eng. 2008, 25, 812-815. [CrossRef]

39. Hsieha, J.-T.; Wang, M.-J.; Lai, J.-T.; Liu, H.-S. A novel static cultivation of bacterial cellulose production by intermittent feeding strategy. J. Taiwan Inst. Chem. Eng. 2016, 63, 46-51. [CrossRef]

40. Uzyol, H.K.; Saçan, M.T. Bacterial cellulose production by Komagataeibacter hansenii using algae-based glucose. Environ. Sci. Pollut. Res. 2017, 24, 11154-11162. [CrossRef] [PubMed]

41. Suwanposri, A.; Yukphan, P.; Yamada, Y.; Ochaikul, D. Statistical optimisation of culture conditions for biocellulose production by Komagataeibacter sp. PAP1 using soya bean whey. Maejo Int. J. Sci. Technol. 2014, 8, 1-14. [CrossRef]

42. Rangaswamy, B.E.; Vanitha, K.P.; Hungund, B.S. Microbial cellulose production from bacteria isolated from rotten fruit. Int. J. Polym. Sci. 2015, 2015, 8. [CrossRef]

43. Jahan, F.; Kumar, V.; Rawat, G.; Saxena, R.K. Production of microbial cellulose by a bacterium isolated from fruit. Appl. Biochem. Biotechnol. 2012, 167, 1157-1171. [CrossRef] [PubMed]

44. Huang, C.; Yang, X.A.; Xiong, L.; Guo, H.-J.; Luo, J.; Wang, B.; Zhang, H.-R.; Lin, X.-Q.; Chen, X.-D. Utilization of corncob acid hydrolysate for bacterial cellulose production by Gluconacetobacter xylinus. Appl. Biochem. Biotechnol. 2015, 175, 1678-1688. [CrossRef] [PubMed]

45. Hong, F.; Zhu, Y.X.; Yang, G.; Yang, X.X. Wheat straw acid hydrolysate as a potential cost-effective feedstock for production of bacterial cellulose. J. Chem. Technol. Biotechnol. 2011, 86, 675-680. [CrossRef]

46. Zeng, X.; Small, D.P.; Wan, W. Statistical optimization of culture conditions for bacterial cellulose production by Acetobacter xylinum BPR 2001 from maple syrup. Carbohydr. Polym. 2011, 85, 506-513. [CrossRef]

47. Tonouchi, N.; Tsuchida, T.; Yoshinaga, F.; Beppu, T.; Horinouchi, S. Characterization of the biosynthetic pathway of cellulose from glucose and fructose in Acetobacter xylinum. Biosci. Biotechnol. Biochem. 1996, 60, 1377-1379. [CrossRef]

48. Efremenko, E.N.; Stepanov, N.A.; Senko, O.V.; Maslova, O.V. Immobilized Biocatalysts for Bacterial Cellulose Production. U.S. Patent 2,636,041, 11 November 2017.

49. Vincenta, M.; Anthony, L.; Pometto, A.L.; van Leeuwen, J.H. Ethanol production via simultaneous saccharification and fermentation of sodium hydroxide treated corn stover using Phanerochaete chrysosporium and Gloeophyllum trabeum. Bioresour. Technol. 2014, 158, 1-6. [CrossRef] [PubMed]

50. Mohammadkazemi, F.; Azin, M.; Ashori, A. Production of bacterial cellulose using different carbon sources and culture media. Carbohydr. Polym. 2015, 117, 518-523. [CrossRef] [PubMed] 